\title{
RESEARCH OF THE MARKET OF CONFECTIONERY OF UKRAINE; TOOLS OF THE RESEARCH OF TILED CHOCOLATE
}

\author{
Ukrainian State University of Chemical Technology, Dnipro, Ukraine
}

\begin{abstract}
Today chocolate is - an integral part of life of any person and, as we know, the best depression medicine. It is used both adults, and children. According to GLOBAL REACH CONSULTING, about $82 \%$ of Ukrainians consume chocolate in this or that form. It in many respects demonstrates to popularity of these products. The market of chocolate products is a segment of the confectionery market and occupies $50-55 \%$ of its volume. In this regard studying of this market is the most relevant. Development of subjects of the market of confectionery in Ukraine happens in the conditions of the changing changes of the external environment influencing their state cause certain social and economic features and problems of development. Transformation of economy of Ukraine makes new demands to behavior of the enterprises. It is result of permanent market saturation new types of confectionery that is caused top trends - constantly changing flavoring preferences of consumers and the competition in the market. The situation is complicated by the general economic instability, inflation, imperfection of the market relations. As a result of the enterprise have dynamically to resolve an issue of assessment of strategy of the behavior not only today, but also in the long term and also to monitor a situation of needs of the population in the sphere of healthy food. Today as abroad, and in Ukraine development of new types of confectionery with the lowered mass fraction of sugar by replacement by natural sweeteners continues. Also these issues are actively discussed in various periodicals and thematic newspapers and magazines. But still there are many problem points in development of subjects of the market of confectionery, development of integrated socially economic approach to forming of efficient market, population requirements satisfaction in confectionery products. The market of confectionery of Ukraine on saturation and the range approaches the European countries. Confectionery Ukraine of the including about 2000 names and assortment structure of the European countries contains about 2300-3000 pieces. More than $90 \%$ of the market of sweets belongs to domestic production. In Ukraine they are made by more than 800 enterprises.
\end{abstract}

Keywords: chocolate, competitiveness of the enterprises, export, import, strategy, market, segment.

DOI: $10.32434 / 2415-3974-2019-9-1-151-157$

\section{Relevance of a subject}

The confectionery market in Ukraine in recent years considerably changed, at the same time assistance of an economic crisis, devaluation of hryvnia, reduction of purchasing power of the population, increase in prices for goods and the situation which developed in the east of Ukraine therefore large owners lost the enterprises. Important factor of the solution of a problem of improving competitiveness, studying of organizational economic bases of its increase, formation of an effective management system.
Purpose of the article

- to study the market of chocolate;

- to obtain the necessary information on capacity and segmentation of the interesting market;

- to define positions of competitors;

- to learn needs of target audience;

- the analysis of the obtained statistical, economic data for entry of a new product into the market capable to take high positions.

For achievement of the goals it is necessary to solve the following problems:

- to define the consumer of this product; 
- to learn the opinion on market products at consumers;

- to obtain information to improve a situation.

Main results

The greatest interest when carrying out marketing researches is attracted by acquaintance with the marketing environment of the company which is everything that surrounds the company, all factors influencing its functioning and it in general.

The research showed that demand in the market of chocolate the same factors which affect the markets of other day-to-day goods have an impact. More precisely, it is external and internal factors.

We will analyze problems and possibilities of the market of macro environment of chocolate products and also their influence.

According to expert evaluation of the importance, taking into account a weight factor, impact is made economic (34\%) and political and legal (21\%), natural (17\%), scientific and technical (13\%), sociocultural (10\%), demographic $(5 \%)$ by factors. Are among economic problems: decrease in purchasing power of the population, increase in prices for cocoa beans and sugar, inflation, export reduction, obvious presence of leaders. Since 2014 the market of confectionery shows a downward tendency what the domestic policy in the state and aggravation of fighting in the east of Ukraine affected that caused problems of the Russian sales market and loss of large factories. For 2016 the situation in production of sweets improves in comparison with 2015. The research of the confectionery market in Ukraine demonstrates that the greatest share is occupied by domestic products, makes about $95 \%$ in a total amount [6].

Presently rates Rostov of income of the population are not in time behind high inflation rates that can lead to decrease in purchasing power of the population, and as a result - to decrease in demand for chocolate products. From the second party, inflation - the reason of rise in price of raw materials for the confectionery industry. It promotes value addition and, respectively, and the prices that can cause decline in demand for products of the company also. All these trends have negative impact on market development in general.

Opportunities much less - import reduction that opens doors for self-produced promotion.

Unfortunately, the Ukrainian confectionery enterprises were not included into top ten world trade. However, according to Gosstat of Ukraine, the confectionery corporation «Roshen» takes the 24th place, CHAO of Konti - 43, ZAO «AVK» -67 . Net volume of sales Ukrainian it is much less producers, than have world leaders. The most powerful among the Ukrainian companies is the ROSHEN corporation numbering 8 factories where
10,000 employees work and net volume is 800 million dollars. 5 factories on 3792 workers are concentrated on Conti's enterprise, sales volume is 469 million dollars that is $1 \%$ less than an indicator of last year, and the AVK company has 3 factories where 3500 workers do, and the net volume of sales is $275 \mathrm{mln}$. dollars [1].

Treat problems of political and legal factors: instability of political country situation and tax policy. There is no confidence in tomorrow. Prior to the military conflict in the east of Ukraine (2014), Russia was the country to which more confectionery were exported, but in the present the largest buyers of the Ukrainian products are neighboring countries and the CIS countries: Kazakhstan - 19\%, Belarus 9\%, Azerbaijan $-8 \%$ and also other countries of the world [5].

The situation is stapler, the consumer income is stables. And the income is higher, the more actively both those, and others are interested in consumer goods. In the nearest future it is going to consider a question of an exit of the Ukrainian goods not only on the European countries, but also on such exotic markets as India, Ghana, Nigeria and China. Products of the confectionery industry are goods with the added value therefore it is necessary to increase their export by foreign markets. Active process became the reason of growth reorientation of exporters of confectionery to international markets, new, often not traditional for Ukraine, after loss of sales market in Russia [2].

Among these goods there is a chocolate. So tomorrow there can be absolutely other legislation.

Among opportunities: development of methods of support of small business which will open free entry into the market for absolutely new producers.

Natural it is possible to carry to problems: rise in price of utility payments, water quality degradation, utilization of a wrapper. It is possible to solve these problems: working with a reduced tariff, installation of the systems of water clarification, use of a foil as secondary raw materials at night, and for some number of products to use paper - ecologically safe.

Scientific technology factors of macromarketing include such opportunities as emergence of new technologies, creation of new, more perfect products. Therefore it is necessary to cooperate closely with scientific and technical producers, to introduce new technologies and to increase production of chocolate with various stuffings, packing.

From sociocultural factors of macro environment treat problems: cultural development of consumption and awareness of health (people not just buy all that offer them in the market, and look for what will be useful therefore it is necessary to improve «healthy» goods, a variety of this number of products through additional researches), 
segmentation of consumer market (reduction of the prices, for the account improvement of production technologies or raw materials).

To opportunities: influence of media on the consumer that will help to advance goods.

Demographic problems concern consumers of different age groupes. It is difficult to diversify the range under each age category, but at additional researches, it is possible to allocate several positions, having connected additional researches and means.

Further it is necessary to evaluate the internal environment.

Consumers are the reason of existence of any enterprise. In Ukraine permanent decrease in demand for chocolate products is observed. The correct strategy of involvement of consumers is important more than ever now. Our differentiated marketing strategy will help us to focus on several segments of the market along with development of individual offers. The release and start of new products, forming of new requirements at consumers, expansion of a share of traditional products will lead us to the market.

It is necessary to attract as much as possible potential consumers, and in the following and to try to hold, the target audience of chocolate products is rather extensive. Purpose of any company: to be the best and to seek to exceed competitors on quality and consumer preferences. We have to expect and react to the changing needs of the consumer and a system eventually, through constant development and innovations [7].

The following a stage - determination of competitors and their position (table). The largest Ukrainian producer of confectionery is ROSHEN corporation, AVK, «Mondelis Ukraina» («Crown», «Milka»), the Lviv confectionery «Svitoch».

It is necessary to watch closely activity of main competitors, not to concede to them neither on quality, nor at the price, is it necessary to be improved and develop in every possible way and by that to try to obtain market position.

As for suppliers, many producers of chocolate in Ukraine buy raw materials from the European partners instead of improving the relations directly with the manufacturing countries. The excessive dependence on the European suppliers weakened competitiveness of domestic manufacturers, and they are gradually forced out by the western companies.
In Ukraine about 800 confectionery enterprises work. At the same time six companies' market leaders «HBF» and Harkovchanka, «AVK», Konti, Roshen, «Zhitomirsk_lasoshch i», OAO «Poltavakonditer» - occupy more than $60 \%$ in structure of national production. Thanks to expansion of production capacities, improvement of quality of products, creation of brands, removal on the market of new products, to carrying out the large-scale promotion and marketing companies they borrowed and at the moment for the present hold the first positions [3]. Most of small producers of confectionery in comparison with large players are poorly modernized, their sales markets are limited, and they have no developed trademarks. They try not to compete with the large companies and to occupy rather free niches, including production of flour confectionery with manual operation use (cakes and cakes), work under the order of retail retail chain stores. With growth of the competition and liberalization of foreign economic relations confectionery with the low level of profitability began to interfere with implementation of advanced technologies by producers, development and market promotion of new trademarks of products taking into account constantly changing flavoring preferences of consumers. In this regard leading companies prefer to get rid of production of cheap confectionery in whole or in part. About $70 \%$ or three quarters of export control 9 more largely - the shikh of the companies - «AVK», «Biscuit chocolate», «Zhitomirsk_Lasoshch_», Konti, «Kraft Fudz Ukraine», Poltavkonditer, Roshen, «Svit Lasoshiv» and «Svitoch» belonging to the Swiss Nestle [4].

For determination of ways of development of the enterprises it is offered to classify criteria of the analysis of the confectionery industry on the following groups: economic; technical; organizational; production; financial; marketing. It will allow revealing trends and the commodity strategy of their use in activity before - acceptance. Special attention should be paid on such marketing characteristics as pricing, segmentation and positioning in the market, communication and channels distributions, competitiveness that forms a certain trajectory of development of the enterprise.

Intermediaries form the marketing capacity of the company through distribution channels of service in a scope of target market and bringing a product

Competitors (from-3 to 3 )

\begin{tabular}{l|c|c|c|c|c}
\hline Factors & of «Sheriy» & of «ROSHEN» & of «Mondelis Ukraina» & of «Svitoch» & of «Millennium» \\
\hline Tastes & +3 & +2 & +1 & -1 & 0 \\
\hline Price & +1 & -1 & -2 & +2 & 0 \\
\hline Range & +1 & +2 & +3 & -2 & -1 \\
\hline Brand & -3 & +3 & +2 & +1 & -1 \\
\hline Design & +1 & +2 & +3 & 1 & 0 \\
\hline
\end{tabular}


to the final consumer. Thus the company intends to use services of distributors in promotion of the products on the market. Researches allow drawing certain conclusions: in market conditions management of commodity strategy is necessary that will increase competitiveness of domestic enterprises of the confectionery industry in the conditions of globalization of economy; the made development evaluation of the market of confectionery testifies to a trend of increase in production. So, growth rates of production of confectionery by data for 2016 in general were $112.6 \%$ in comparison with 2017. However in 2019 owing to the global financial crisis, there was increase in prices for all types of the made confectionery products that led to decrease in purchasing power and to sales reduction of the main operators of the confectionery market; it is in our opinion recommended to revise the business strategy of producers of confectionery directed to reduction of chocolate products of a premium class in connection with decrease in the sales demand and to increase production of inexpensive caramel, demand by which in the current year sharply grew; for ensuring the progressing saturation of requirements of the confectionery market it is necessary to use as much as possible benefits of such segment as the market of flour confectionery and also to production of sugary confectionery, and tiled chocolate.

As the basic tool of a research the sociological survey conducted among direct consumers of chocolate was used.

In a work progress, this purpose, necessary for achievement, the following events were held:

- Development of questionnaires and tools of a research;

- Questioning;

- Preprocessing of data;

- Analysis, statistical and economic data handling [6].
In questioning 100 people ( $90 \%$ by means of social networks) from which took part: $69 \%$ women, and $31 \%$ - men; aged up to 20 years $20 \%, 20-30$ years $-69 \%, 30-45$ years $-6 \%$, $45-$ 60 years $-4 \%$, of 60 years $-1 \%$; kind of activity of consumers: school students $-4 \%$, students $-49 \%$, working $-46 \%$, pensioners $-1 \%$.

Motives of purchase of chocolate (it was possible to choose a little at once):

-82 - taste of chocolate;

-48 - quality;

- 34 - price;

-14 - packing;

- 45 - brand;

$-10-$ advice of the friends and acquaintances (fig. 1).

Among consumers of chocolate, frequency is purchase and consumption of popular goods is:

$-18 \%$ - every day

$-34 \%-2-3$ times a week

$-31 \%$ - once a week

$-15 \%$ - once a month (fig. 2).

$-2 \%$ - are more rare than 1 time a month

The most popular brands: «ROSHEN», «Mondelis Ukraina» («Milka», «Crown»), «Svitoch», «Millennium», Others: «AVK» and «Ritter sport» (fig. 3).

Among the consumers buying chocolate, the reasonable price of one tile is: $9 \%$ - up to $20 \mathrm{UAH}$, $71 \%$ - 20 - $40 \mathrm{UAH}, 20 \%$ - from $40 \mathrm{UAH}$.

Buying tiled chocolate, have different flavoring preferences: $9 \%$ - dark, $81 \%$ - dairy, $4 \%$ - white, $6 \%$ - the main thing, that with filler.

Among the interviewed consumers of chocolate, such preferences of kinds of a stuffing were marked out: $78 \%$ are nuts, $4 \%$ - raisin, $8 \%$ - cookies, $7 \%-$ jam, $1 \%$ - fruit jelly, $1 \%$ - an orange dried peel (fig. 4).

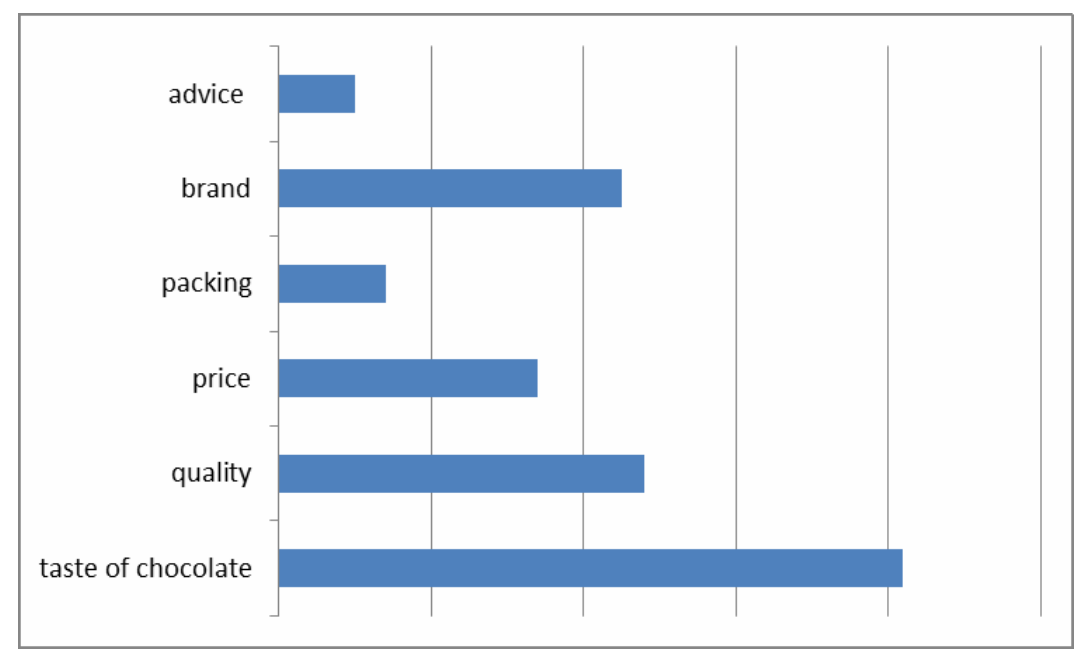

Fig. 1. Motives of purchase of chocolate 
Research of the market of confectionery of Ukraine; Tools of the research of tiled chocolate

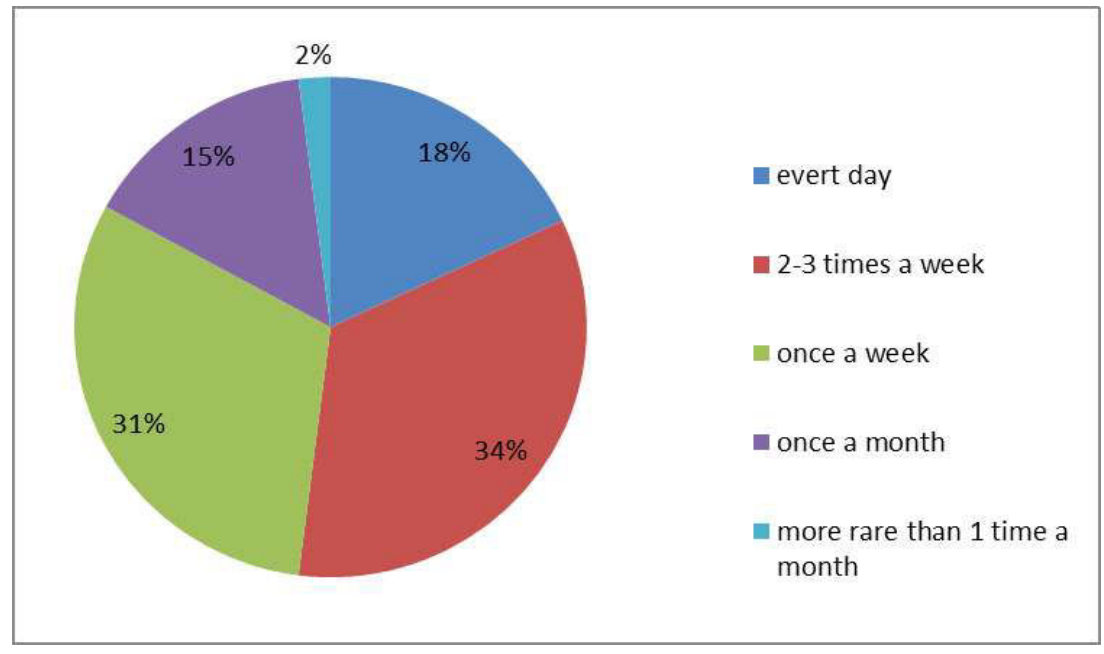

Fig. 2. Chocolate frequency

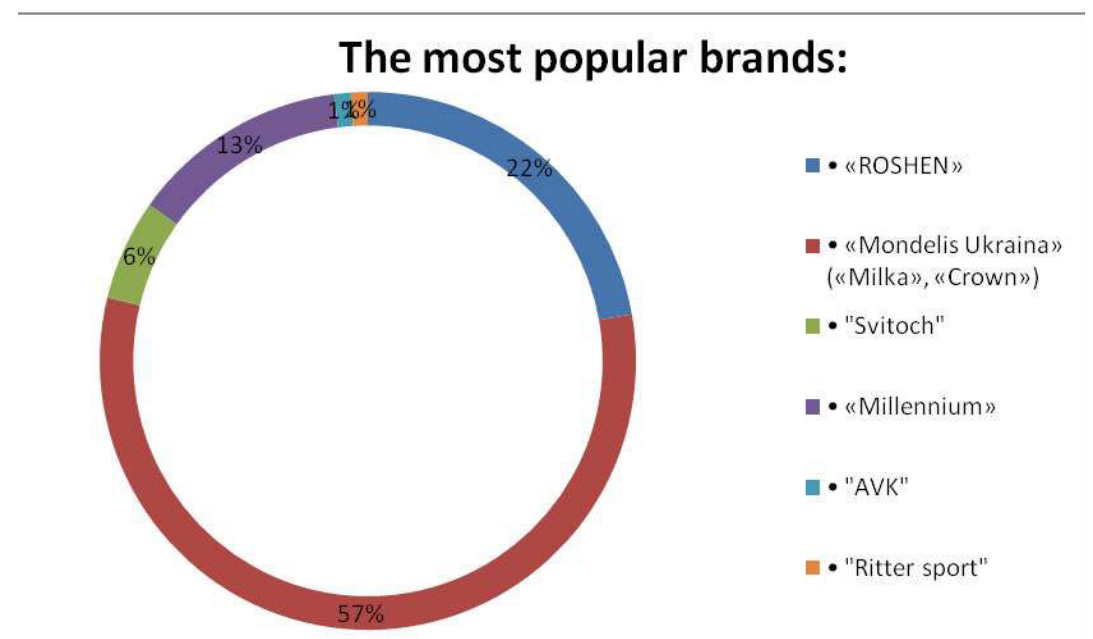

Fig. 3. The most popular brands

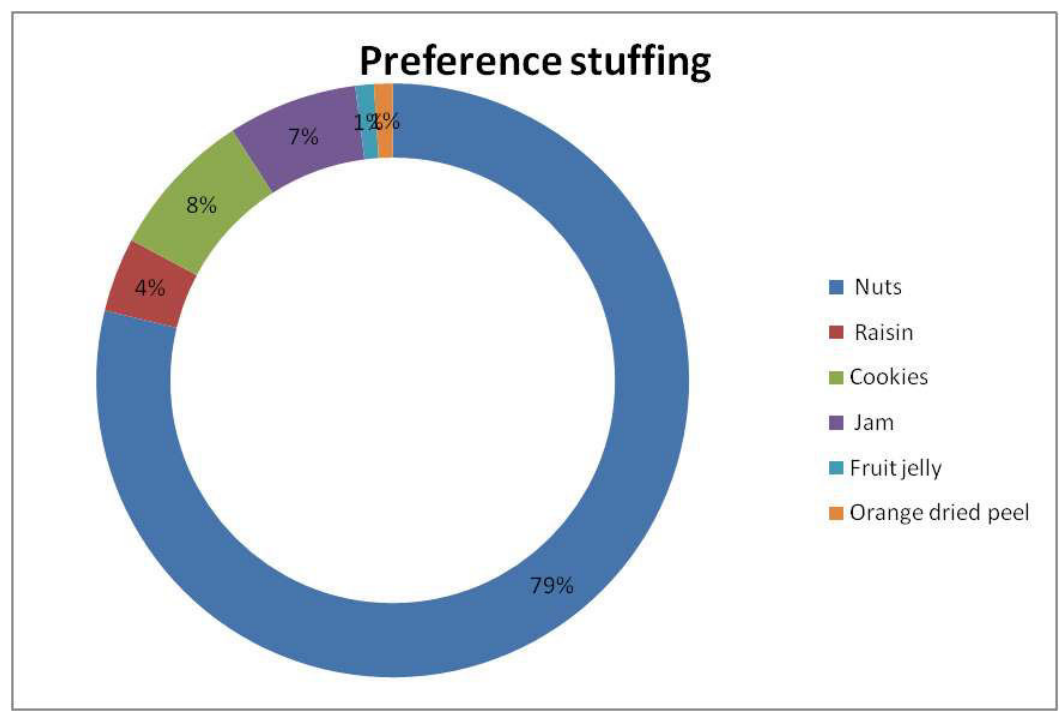

Fig. 4. Preference stuffing 
Answered the question «Having Seen Advertising of a New Product whether You Will Go to Buy It» so: There are no 32\%-39\% find it difficult to answer and only $29 \%$ answered yes.

\section{Conclusions}

Chocolate industry in Ukraine is rather powerful and developed among others food industries. Production of confectionery promptly develops and has sufficient product competitiveness in international market. Having analyzed the confectionery market, it is possible to draw a conclusion that despite difficult economic situation in Ukraine, entrepreneurs do everything possible to keep the status of producers of a high-quality product.

Economic and political and legal factors as the market of chocolate is under the threat, first of all because of such changes as inflation, increase in prices for cocoa beans, increase in taxes and falling of the general level of living now have the greatest impact. Such situation can lead to decrease in profitability of production and suspension of work of the separate enterprises. In this industry, certainly, there will be a reduction of personnel. Would help to hold buyers price stabilization in the market of cocoa, but it does not depend on the Ukrainian producers. However in their forces to change policy of purchases at the European suppliers and to begin to improve partnership directly with the manufacturing countries.

The research showed that:

1. Women prefer chocolate more, than men;

2. Respondents consumed chocolate on average 2-3 times a week;

3. Most of respondents prefer nut chocolate;

4. A large number of respondents, choosing chocolate, are guided mostly by what taste and quality of this product.

5. The price, acceptable for respondents, is from 20 to $40 \mathrm{UAH}$

6. Most of respondents give preference to chocolate brands: ROSHEN and «Mondelis Ukraine».

7. Most of respondents prefer milk chocolate.

\section{REFERENCES}

1. Kornikovsky D.A. Analysis of economic factors of influence on the confectionery industry of Ukraine // Economy of the food industry. -2014 . - P.47.

2. Zakrevskaya L.N. Current state and prospects of development of export policy of the enterprises of a candy store industries of Ukraine // Economy: problems of the theory and practice: - M: LNU, 2015 - P.165.

3. Export import of separate types of goods over the countries of the world [An electronic resource] // Public service statistics of Ukraine. - Access mode: http://www.ukrstat.gov.ua
4. State committee of statistics of Ukraine // Production main types of industrial output on months, 2009.

5. Vasilisa E. Overview of the market of sugary confectionery // Analytics of Credit-Reyting Rating agency, 2010.

6. Strelnikova D.A. Market development evaluation confectionery products of Ukraine, 2009.

7. Ukrainian market of confectionery // Advertiser // Statistics and analysis, 2008.

8. Commodity structure of foreign trade for 2011 and 2012. - [Electronic resource]. - Access mode: www.ukrstut.gov.ua

Received 10.04.19

Reviewer: prof. Kolesnikov V.P.

\section{ДОСЛІДЖЕННЯ РИНКУ КОНДИТЕРСЬКИХ ВИРОБІВ УКРАЇНИ; ІНСТРУМЕНТИ ДОСЛІДЖЕННЯ МОЗАЙЧНОГО ШОКОЛАДУ}

\section{Слюта А.О., Журавель В.В., Парій С., Шевченко Я.}

Сьогодні шоколад - невід' ємна частина життя будьякої людини i, як відомо, найкращі депресивний ліки. Використовується як дорослим, так і дітям. За словами GLOBAL REACH CONSULTING, близько $82 \%$ українців споживають шоколад в тій чи іншій формі. Вона багато в чому демонструє популярність цих продуктів. Ринок шоколадних виробів є сегментом кондитерського ринку $i$ займає 50-55\% його обсягу. $B$ цьому плані вивчення цього ринку є найбільш актуальним. Розвиток суб' єктів ринку кондитерських виробів в Україні відбувається в умовах мінливих змін зовнішнього середовища, що впливають на їх стан, викликають певні соціально-економічні особливості і проблеми розвитку. Трансформація економіки України висуває нові вимоги до поведінки підприємств. Саме в результаті постійного насичення ринку новими видами кондитерських виробів виникають топ тренди - постійно мінливі смакові переваги споживачів і конкуренції на ринку. Ситуація ускладнюється загальною економічною нестабільністю, інфляцією, недосконалістю ринкових відносин. В результаті підприємству належить динамічно вирішувати питання оцінювання стратегії поведінки не тільки сьогодні, але і в довгостроковій перспективі і також стежити за ситуацією з потребами населення у сфері здорового харчування. Сьогодні як за кордоном, так $і$ в Україні триває розробка нових видів кондитерських виробів зі зниженою масовою часткою иукру шляхом заміни на натуральні підсолоджувачі. Також ці питання активно обговорюються в різних періодичних виданнях і тематичних газетах $і$ журналах. Але все же є багато проблемних моментів у розвитку суб'єктів ринку кондитерських виробів, розвитку комплексного соціально-економічного підходу до формування ефективного ринку, задоволенні потреб населення в кондитерських виробах. Ринок кондитерських виробів України за насиченням та асортиментом наближається до європейських країн. Кондитерська Україна в тому числі близько 2000 найменувань і асортиментної структури європейських країн містить близько 23003000 штук. Більще 90\% ринку солодощів належить вітчизняному виробнику. На Україні їх роблять більш 800 підприємств.

Ключові слова: шоколад, конкурентоспроможність підприємств, експорту, імпорту, стратегії, ринку, сегмента. 


\section{ИССЛЕДОВАНИЕ РЫНКА КОНДИТЕРСКИХ ИЗДЕЛИЙ УКРАИНЫ; ИНСТРУМЕНТЫ ИССЛЕДОВАНИЯ МОЗАИЧНОГО ШОКОЛАЛА}

\section{Слюта А.О., Журавель В.В., Парий С., Невченко Я.}

Сегодня шоколад - неотбемлемая часть жизни любого человека и, как известно, лучшее депрессивное лекарство. Используется как взрослым, так и детям. По словам GLOBAL REACH CONSULTING, около 82\% украинцев потребляют шоколад в той или иной форме. Она во многом демонстрирует популярность этих продуктов. Рынок шоколадных изделий является сегментом кондитерского рынка и занимает 50-55\% его объема. В этом плане изучение этого рынка является наиболее актуальным. Развитие субъектов рынка кондитерских изделий в Украине происходит в условиях меняющихся изменений внешней среды, влияющих на их состояние, вызывают определенные социально-экономические особенности и проблемы развития. Трансформация экономики Украины выдвигает новые требования к поведению предприятий. Именно в результате постоянного насыщения рынка новыми видами кондитерских изделий возникают топ-тренды - постоянно меняющиеся вкусовые предпочтения потребителей и конкурениия на рынке. Ситуация осложняется общей экономической нестабильностью, инфляцией, несовершенством рыночных отношений. В результате предприятию предстоит динамично решать вопрос оценки стратегии поведения не только сегодня, но и в долгосрочной перспективе и также следить за ситуацией с потребностями населения в сфере здорового питания. Сегодня как за рубежом, так и в Украине продолжается разработка новых видов кондитерских изделий с пониженной массовой долей сахара путем замены на натуральные подсластители. Также эти вопросы активно обсуждаются в различных периодических изданиях и тематических газетах и журналах. Но все же есть много проблемных моментов в развитии субвектов рынка кондитерских изделий, развитии комплексного социально-экономического подхода к формированию эффективного рынка, удовлетворении потребностей населения в кондитерских изделиях. Рынок кондитерских изделий Украины по насыщению и ассортименту приближается к европейским странам. Кондитерская Украина в том числе около 2000 наименований и ассортиментной структуры европейских стран содержит около 2300-3000 штук. Более 90\% рынка сладостей принадлежит отечественному производству. На Украине их делают более 800 предприятий.

Ключевые слова: шоколад, конкурентоспособность предприятий, экспорта, импорта, стратегии, рынка, сегмента.

\section{RESEARCH OF THE MARKET OF CONFECTIONERY OF UKRAINE; TOOLS OF THE RESEARCH OF TILED CHOCOLATE}

Slyuta A.O., Zhuravel V.V. ", Pariahs S., Shevchenko Y. Ukrainian State University of Chemical Technology, Dnipro, Ukraine

\section{* e-mail: zhuravelao094@gmail.com}

Today chocolate is - an integral part of life of any person and, as we know, the best depression medicine. It is used both adults, and children. According to GLOBAL REACH CONSULTING, about $82 \%$ of Ukrainians consume chocolate in this or that form. It in many respects demonstrates to popularity of these products. The market of chocolate products is a segment of the confectionery market and occupies 50-55\% of its volume. In this regard studying of this market is the most relevant. Development of subjects of the market of confectionery in Ukraine happens in the conditions of the changing changes of the external environment influencing their state cause certain social and economic features and problems of development. Transformation of economy of Ukraine makes new demands to behavior of the enterprises. It is result of permanent market saturation new types of confectionery that is caused top trends - constantly changing flavoring preferences of consumers and the competition in the market. The situation is complicated by the general economic instability, inflation, imperfection of the market relations. As a result of the enterprise have dynamically to resolve an issue of assessment of strategy of the behavior not only today, but also in the long term and also to monitor a situation of needs of the population in the sphere of healthy food. Today as abroad, and in Ukraine development of new types of confectionery with the lowered mass fraction of sugar by replacement by natural sweeteners continues. Also these issues are actively discussed in various periodicals and thematic newspapers and magazines. But still there are many problem points in development of subjects of the market of confectionery, development of integrated socially economic approach to forming of efficient market, population requirements satisfaction in confectionery products. The market of confectionery of Ukraine on saturation and the range approaches the European countries. Confectionery Ukraine of the including about 2000 names and assortment structure of the European countries contains about 2300-3000 pieces. More than $90 \%$ of the market of sweets belongs to domestic production. In Ukraine they are made by more than 800 enterprises.

Keywords: chocolate, competitiveness of the enterprises, export, import, strategy, market, segment.

References

1. Kornikovsky D.A. Analysis of economic factors of influence on the confectionery industry of Ukraine. / D.A. Kornikovsky//Economy of the food industry. - 2014. - Page 47.

2. Zakrevskaya L. N. Current state and prospects of development of export policy of the enterprises of a candy store industries of Ukraine/L. N. Zakrevskaya//Economy: problems of the theory and practice: - M: LNU, 2015 - Page 165.

3 . Export import of separate types of goods over the countries of the world [An electronic resource]//Public service statistics of Ukraine. - Access mode: http://www.ukrstat.gov.ua

4. State committee of statistics of Ukraine//Production main types of industrial output on months, 2009;

5. Vasilisa E. Overview of the market of sugary confectionery//Analytics of Credit-Reyting Rating agency, 2010

6. D.A. Strelnikova: Market development evaluation confectionery products of Ukraine, 2009

7. Ukrainian market of confectionery//Advertiser//Statistics and analysis, 2008

8. Commodity structure of foreign trade for 2011 and 2012. [Electronic resource]. - Access mode: www.ukrstut.gov.ua 